\title{
Efektivitas Isolat-Isolat Bacillus sebagai Pengendali Penyakit Bulai dan Pemacu Pertumbuhan Tanaman Jagung pada Kondisi Terkontrol
}

\author{
Syaiful Khoiri ${ }^{1 *}$, Kaswan Badami ${ }^{1}$, Gita Pawana ${ }^{1}$, Ciwuk Sri Utami ${ }^{1}$ \\ ${ }^{1}$ Prodi Agroteknologi Fakultas Pertanian Universitas Trunojoyo Madura \\ Jl. Raya Telang No 02 Kamal Bangkalan Madura 69162 Jawa Timur \\ *syaiful.khoiri@trunojoyo.ac.id \\ DOI: https://doi.org/10.21107/rekayasa.v14i2.10270
}

\begin{abstract}
The main disease in maize is downy mildew caused by the fungus Peronosclerospora spp.. This pathogen can cause yield losses of up to 100\%. Therefore, efforts to control this disease are continuously carried out, including technical culture, assembly of resistant plants, and use of synthetic fungicides. At the farm level, the use of metalaxyl, synthetic fungicides is the most common practice. On the other hand, it has been reported that some Peronosclerospora groups are starting to become resistant to metalaxyl. These problems lead to the need for alternative controls, for example with biological agents. Biological agents from bacterial groups have been developed to control plant disease, but for downy mildew is still limited. The purpose of this study is to screen and test Bacillus spp. ability to suppress downy mildew and promote the growth of maize. The assay was carried out on seeds by invitro to investigate growth-promoting reactions and also testing under controlled conditions in greenhouses to investigate the suppression ability of downy mildew disease development. The results showed B. polymyxa strain BP18, Bacillus subtilis strain BS41, Bacillus sp. strain BT1, and Bacillus sp. strains can stimulate the growth of corn seedlings and suppress downy mildew. The best isolate in suppressing downy mildew was Bacillus sp. strain BT1 with the smallest AUDPC value (3.94) and the highest protection index (82.71\%). It is hoped that these results will find potential isolates and have the potential to be developed into biopesticides and biofertilizers.
\end{abstract}

Keywords : biopesticide, growth promotion, index protection, maize, peronosclerospora

\section{PENDAHULUAN}

Jagung merupakan salah satu komoditas utama yang menjadi perhatian Pemerintah. Kementrian Pertanian telah melakukan berbagai upaya dalam peningkatan produksi selama 3 tahun terakhir dan menghasilkan capaian yang menggembirakan. Berdasarkan data tahun 2016, produksi jagung Indonesia sekitar 23,58 juta ton atau meningkat 20,22\% dari produksi tahun 2015 sebesar 19,61 juta ton. Produksi tahun 2017 kembali meningkat 10,39\% menjadi 26,03 juta ton (Badan Pusat Statistik (BPS), 2018). Di Madura, jagung merupakan komoditas utama yang banyak ditanam dengan luasan 301.725 hektar atau 30\% luas area jagung di Jawa Timur. Produksi jagung di Indonesia pada tahun 2018 mencapai 30,05 juta ton dengan produksi di Jawa Timur 6,03 juta ton atau setara

\section{Article History:}

Received: March, 30 2021; Accepted: June, 27 2021

Rekayasa ISSN: 2502-5325 has been Accredited by Ristekdikti (Arjuna) Decree: No. 23/E/KPT/2019 August 8th, 2019 effective until 2023 dengan 20\% produksi nasional (Kementerian Pertanian, 2019).

Upaya-upaya peningkatan produksi terus dilakukan, namun ada beberapa faktor pembatas yang dapat berpengaruh terhadap produksi jagung. Salah satu permasalahan yang dapat menurunkan produksi jagung adalah adanya organisme pengganggu tanaman (OPT). OPT utama pada tanaman jagung adalah penyakit bulai. Penyakit bulai dapat disebabkan oleh Peronosclerospora maydis, $P$. sorghi, atau $P$. philipinensis. Penyakit bulai yang disebabkan cendawan Peronoslerospora merupakan penyakit penting yang telah dilaporkan diseluruh dunia yang menyerang jagung dan

\section{Cite this as:}

Khoiri, S., Badami, K., Pawana, G \& Utami, C.S. (2021). Efektifitas Isolat-Isolat Bacillus sebagai Pengendali Bulai dan Pemacu Pertumbuhan Tanaman Jagung pada Kondisi Terkontrol. Rekayasa 14 (2). 144-151.

doi: https://doi.org/10.21107/rekayasa.v14i2.10270.

(C) 2021 Syaiful Khoiri, Kaswan Badami, Gita Pawana \& Ciwuk Sri Utami 
sorgum. Cendawan patogen ini dapat menginfeksi secara lokal dan sistemik pada kedua inang tersebut (Bonman, Paisooksantivatana, \& Pitipornchai, 1983) dan menyebabkan perunuran produksi yang signifikan. Laporan kehilangan hasil akibat penyakit ini berkisar $50-80 \%$ di beberapa wilayah sentra pengembangan jagung seperti Jawa Timur, Sulawesi Selatan dan Kalimantan Barat (Amran, Suriany, \& Nurnina, 2018; Pakki, 2017; Rustiani, Sinaga, Hidayat, \& Wiyono, 2015).

Pengendalian penyakit bulai ini umumnya menggunakan perlakuan benih dengan fungisida sistemik, metalaksil (Anahosur, 1980), namun penggunakan fungisida sintetik ini dapat menyebabkan penceramaran pada lingkungan dan ekosistem, Sehingga pengendalian dengan menggunakan fungisida ini tidak dapat mengendalikan dalam jangka waktu yang lama. Selain itu, Isakeit dan Jaster (2005) melaporkan bahwa $P$. sorghi telah tahan terhadap fungisida. Teknik pengendalian lain dengan varietas yang tahan juga terus dikembangkan namun belum ada varietas yang dilaporkan sangat tahan terhadap serangan bulai (Rashid, Zaidi, Vinayan, Sharma, \& Setty, 2013). Sehingga perlu dikembangkan metode-metode pengendalian lain seperti pemanfaatan bakteri agens hayati.

Agens hayati Bacillus sublilis G1 telah dilaporkan dapat menekan kejadian penyakit hingga $50 \%$, selain itu $B$. subtilis G1 tersebut mampu meningkatkan persentase perkecambahan dan memperbaiki vigor tanaman jagung (Sireesha \& Velazhahan, 2016). Namun, di Indonesia pengembangan agens hayati untuk penyakit bulai sekaligus sebagai pupuk hayati ini masih terbatas. Sehingga perlu dilakukan pengujian isolat-isolat bakteri yang berpotensi sebagai agens hayati dan pupuk hayati. Harapannya dapat ditemukan alternatif pengendalian penyakit bulai pada tanaman jagung menggunakan bakteri yang bermanfaat.

\section{METODE PENELITIAN}

\section{Waktu dan Tempat Penelitian}

Penelitian dilakukan mulai bulan Juli 2020 sampai dengan Desember 2020. Penelitian dilakukan di Laboratorium Proteksi Tanaman dan Rumah Kaca Program Studi Agroekoteknologi, Fakultas Pertanian, Universitas Trunojoyo Madura.

\section{Alat dan Bahan}

Alat-alat yang digunakan dalam penelitian ini adalah laminar air flow cabinet, cawan petri, autoklaf, pipet mikro, tabung erlenmeyer, tabung reaksi, lup inokulasi, sprayer, ember, polybag, penggaris, dan kamera. Sedangkan bahan-bahan yang digunakan dalam penelitian ini adalah isolatisolat bakteri koleksi (Tabel 3), media Nutrient broth (NB), agar, aquades, kertas saring, benih jagung varietas Madura-3, kertas serap, tanah, pasir, dan kompos.

\section{Peremajaan Isolat-isolat Bakteri}

Stok isolat-isolat bakteri potensial diremajakan dengan cara ditumbuhkan pada media NB agar (NA) yang telah dituang dalam cawan petri. Inokulasi dilakukan dengan metode gores kuadran. Selanjutnya, isolat-isolat diinkubasi pada suhu ruang selama $48 \mathrm{jam}$. Isolat yang tumbuh diremajakan tiap 48 jam pada media NA.

\section{Pengujian Keefektifan Isolat Bakteri Pengujian pengaruh isolat bakteri pada benih jagung}

Penapisan awal terhadap isolat-isolat potensial koleksi Laboratorium Proteksi Tanaman, Agroekoteknologi, Fakultas Pertanian, Universitas Trunojoyo Madura adalah dengan menguji terhadap perkecambahan benih. Perlakuan bakteri pada benih dilakukan dengan cara merendam benih jagung sebanyak 20 gram dalam $100 \mathrm{~mL}$ suspensi bakteri dan diinkubasi selama 6 jam dengan tujuan supaya bakteri menempel pada benih. Benih kemudian dikeringanginkan selama 2 jam. Pengujian daya kecambah benih dilakukan dengan rolled test pada kertas serap. Benih yang telah ditanam dalam kertas gulung (roller) diinkubasi pada suhu ruang $25 \pm 2^{\circ} \mathrm{C}$ selama satu minggu. Perlakuan sama untuk masing-masing isolat dan kontrol (Sireesha \& Velazhahan, 2016).

\section{Penyiapan sumber inokulum Peronosclerospora spp.}

Sumber inokulum penyakit bulai didapatkan dari daun tanaman jagung yang terinfeksi bulai di lapangan. Daun diambil pada sore hari kemudian diletakkan ke dalam kantong plastik klip. Daun jagung kemudian dicuci menggunakan air bersih dengan tujuan menghilangkan kotoran yang tersisa seperti spora yang telah rusak, kemudian dikeringanginkan. Selanjutnya pangkal daun 
direndam menggunakan larutan gula $2 \%$ setinggi 3 $\mathrm{cm}$ dan disungkup menggunakan plastik klip untuk menjaga kelembabannya, Daun diinkubasi gelap sampai pukul 04.00 WIB. Pukul 04.00 WIB daun dicuci dengan aquades untuk dipanen konidia yang tercuci bersama air. Inokulasi dilakukan pada pagi hari sekitar jam 05.00-06.00 atau sebelum matahari terbit dengan cara menyemprotkan suspensi Peronosclerospora spp. pada setiap bagian tanaman jagung dan titik tumbuh sebanyak $10 \mathrm{~mL}$ (Adhi, Widiantini, \& Yulia, 2019). Tanaman jagung yang sudah terinfeksi bulai sekitar $70 \%$ dari total sumber infeksi kemudian diletakkan diantara tanaman uji sebagai sumber infeksi alami. Identifikasi Peronosclerospora spp. mengikuti metode Rustiani et al., (2015).

\section{Pengujian pengaruh isolat bakteri terhadap penyakit bulai di rumah kaca}

Pengujian kemampuan isolat bakteri dalam menekan penyakit bulai dilakukan pada kondisi lingkungan terkontrol dirumah kaca atau kebun percobaan. Formulasi bakteri disiapkan dengan mencampurkan $400 \mathrm{~mL}$ suspensi bakteri (kerapatan

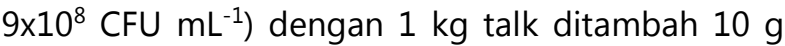
CMC secara aseptik (Vidhyasekaran \& Muthamilan, 1995). Benih jagung yang telah disterilisasi permukaan diberi perlakuan formulasi $10 \mathrm{~g} \mathrm{~kg}^{-1}$ dan ditanam pada polibag diameter $30 \mathrm{~cm}$ yang berisi tanah dan pasir (2:1). Perlakuan kontrol dilakukan dengan menambahkan formula talk+CMC tanpa bakteri. Masing-masing pot berisi satu benih. Tiap lima tanaman dianggap 1 ulangan. Perlakuan diulang dengan empat ulangan. Pengamatan tinggi tanaman, kejadian, dan keparahan penyakit dilakukan setiap minggu selama 5 minggu.

\section{Parameter Pengamatan}

Aktivitas pemacu pertumbuhan bakteri terhadap benih jagung dilakukan dengan cara pengamatan vigor benih berdasarkan standar International Seed testing Association (ISTA, 2017). Pengamatan daya kecambah, panjang akar, dan tinggi tanaman dilakukan setelah inkubasi 7 hari pada pengujian rolled test. Sedangkan parameter penyakit bulai dilakukan perhitungan skoring penyakit mengikuti skala yang dilakukan oleh Matruti et al., (2018). Kejadian penyakit (KJP) dihitung menggunakan Formula 1. Sedangkan penilaian penyakit (skoring) mengikuti skala kerusakan penyakit bulai tersaji pada Tabel 1. Keparahan penyakit dihitung mengikuti formula yang digunakan oleh Ulhaq dan
Masnilah (2019) pada Formula 2. Penentuan kategori ketahanan penyakit bulai mengikuti Daryono et al. (2018) yang tersaji pada Tabel 2. Nilai luas area dibawah kurva perkembangan penyakit (area under disease progress curve/AUDPC) dihitung menggunakan Formula 3. Sedangkan laju perkembangan penyakit $B$ dihitung dengan Formula 4 (Plank 1963; Ginting et al., 2020). Berdasarkan nilai AUDPC dihitung nilai indeks proteksi dengan menggunakan Formula 5 (Caulier et al., 2018).

$$
K J P=\frac{\text { Jumlah tanaman bergejala }}{\text { Jumlah seluruh tanaman yang diamati }} \times 100 \ldots \ldots \ldots \text { (1) }
$$

Tabel 1. Penilaian penyakit bulai

\begin{tabular}{ll}
\hline \multicolumn{1}{c}{$\begin{array}{c}\text { Skala } \\
\text { kerusakan }\end{array}$} & \multicolumn{1}{c}{ Deskripsi gejala } \\
\hline 0 & Tidak ada gejala \\
1 & Luas gejala pada daun $1-25 \%$ \\
2 & Luas gejala pada daun $26-50 \%$ \\
3 & Luas gejala pada daun $51-75 \%$ \\
4 & Luas gejala pada daun $75-100 \%$ \\
\hline
\end{tabular}

Tabel 2. Kategori ketahanan penyakit bulai

\begin{tabular}{ll}
\hline $\begin{array}{l}\text { Intensitas } \\
\text { serangan }\end{array}$ & \multicolumn{1}{c}{ Kategori ketahanan } \\
\hline 0 & Sangat tahan \\
$0<x \leq 25$ & Tahan \\
$25<x \leq 50$ & Agak tahan \\
$50<x \leq 75$ & Tidak tahan \\
$x>75$ & Sangat tidak tahan \\
\hline
\end{tabular}

$$
K P=\frac{\sum\left(n_{i}+v_{i}\right)}{V . Z} 100 \%
$$

Keterangan:

$$
\begin{aligned}
\mathrm{KP} & =\text { Keparahan penyakit } \\
\mathrm{n}_{\mathrm{i}} & =\text { jumlah daun sakit kategori skala ke-i } \\
\mathrm{V}_{\mathrm{i}} & =\text { nilai skala }(0-4) \text { tanaman ke-i } \\
\mathrm{V} & =\text { Nilai skala tertinggi } \\
\mathrm{Z} & =\text { Total tanaman diamati }
\end{aligned}
$$

$$
A U D P C=\sum_{i=1}^{n-1}\left(\frac{y_{i}+y_{i+1}}{2}\right)\left(t_{i+1}-t_{i}\right) \ldots \ldots \ldots \ldots(3)
$$

Keterangan:

AUDPC = Luas area di bawah kurva perkembangan penyakit

$\mathrm{y}_{\mathrm{i}} \quad=$ nilai keparahan ke-i

$\mathrm{t}_{\mathrm{i}} \quad=$ waktu pengamatan ke-i

$$
r=\frac{1}{t_{2}-t_{1}}\left(-\ln \left(-\ln \left(X_{2}\right)\right)+\ln \left(-\ln \left(X_{2}\right) \ldots \ldots\right.\right.
$$

Keterangan: 
$r=$ laju perkembangan keparahan penyakit per hari

$\mathrm{X}_{1 \mathrm{i}}=$ Nilai keparahan penyakit pada pengamatan ke-1

$\mathrm{X}_{2}=$ Nilai keparahan penyakit pada pengamatan ke-2

$t_{1 i}=$ waktu pengamatan ke-1

$\mathrm{t}_{2}=$ waktu pengamatan $\mathrm{ke}-2$

Indeks proteksi $=\left[\left(1-\frac{\text { AUDPC perlakuan }}{\text { AUDPC kontrol }}\right) * 100\right]$.

\section{HASIL DAN PEMBAHASAN}

\section{Peremajaan Isolat-Isolat Uji}

Hasil peremajaan isolat-isolat potensial koleksi Laboratorium Proteksi Tanaman menunjukkan bahwa beberapa isolat tidak dapat ditumbuhkan. Adapun isolat-isolat yang berhasil diremajakan yaitu isolat BS09, BP18, BS41, BT1, BT2, BT3, dan BT4 yang tersaji pada Tabel 3. Isolat yang tumbuh menunjukkan kemampuan atau ketahanan dalam masa penyimpanan. Ketahanan dalam penyimpanan atau disebut periode simpan yang lama merupakan salah satu kriteria agens hayati yang baik untuk di kembangkan. Periode simpan juga sangat dipengaruhi oleh bahan-bahan yang digunakan untuk menyimpan (Kusumanigtyas, 2015)

Tabel 3. Isolat-Isolat Koleksi Laboratorium yang Digunakan dalam Penelitian \& Hasil Peremajaannya Pada Media NA

\begin{tabular}{|c|c|c|c|c|}
\hline No. & $\begin{array}{l}\text { Kode } \\
\text { Isolat }\end{array}$ & Nama Isolat & Asal isolat & Keterangan \\
\hline 1 & BT2 & $\begin{array}{l}\text { Bacillus thuringiensis } \\
\text { BT2 }\end{array}$ & Bogor & $\begin{array}{l}\text { Tidak } \\
\text { tumbuh }\end{array}$ \\
\hline 2 & BS1 & Bacillus subtilis BS1 & Bogor & $\begin{array}{l}\text { Tidak } \\
\text { tumbuh }\end{array}$ \\
\hline 3 & BB6 & $\begin{array}{l}\text { Brevibacillus brevis } \\
\text { BB6 }\end{array}$ & Bogor & $\begin{array}{l}\text { Tidak } \\
\text { tumbuh }\end{array}$ \\
\hline 4 & BS09 & Bacillus sp. BS09 & Pamekasan & Tumbuh \\
\hline 5 & BPs7 & $\begin{array}{l}\text { Paenibacillus } \\
\text { polymixa BPs7 }\end{array}$ & Bogor & $\begin{array}{l}\text { Tidak } \\
\text { tumbuh }\end{array}$ \\
\hline 6 & BS34 & Bacillus subtilis BS34 & Bogor & $\begin{array}{l}\text { Tidak } \\
\text { tumbuh }\end{array}$ \\
\hline 7 & BA5 & $\begin{array}{l}\text { Bacillus } \\
\text { amyloliquifaciens } \\
\text { BA5 }\end{array}$ & Bogor & $\begin{array}{l}\text { Tidak } \\
\text { tumbuh }\end{array}$ \\
\hline 8 & BP18 & $\begin{array}{l}\text { Bacillus polymixa } \\
\text { BP18 }\end{array}$ & Pamekasan & Tumbuh \\
\hline 9 & BS41 & Bacillus subtilis BS41 & Pamekasan & Tumbuh \\
\hline 10 & BT1 & Bacillus sp. BT1 & Bangkalan & Tumbuh \\
\hline 11 & BT2 & Bacillus sp. BT2 & Bangkalan & Tumbuh \\
\hline 12 & BT3 & Bacillus sp. BT3 & Bangkalan & Tumbuh \\
\hline 13 & BT4 & Bacillus sp. BT4 & Bangkalan & Tumbuh \\
\hline
\end{tabular}

\section{Pengaruh Bacillus spp. terhadap Pertumbuhan Benih Jagung}

Salah satu langkah penapisan dan seleksi isolat pemacu pertumbuhan dapat dilakukan dengan melihat pengaruh pertumbuhan pada awal perkecambahan. Hasil pengujian menunjukkan bahwa isolat-isolat yang diuji memiliki pengaruh yang berbeda-beda. Berdasarkan data persentase perkecambahan, isolat tidak mempengaruhi perkecambahan, bahkan isolat BS41, BT3, dan BT4 menunjukkan persentase perkecambahan benih $100 \%$. Sedangkan dari parameter pertumbuhan tajuk dan akar jagung menunjukkan isolat $B$. polymyxa strain BP18, Bacillus subtilis strain BS41, Bacillus sp. strain BT1, dan Bacillus sp. strain BT2 menunjukkan pengaruh pertumbuhan yang lebih baik dibandingkan dengan kontrol (Tabel 4, Gambar 1).

Tabel 4. Pengaruh Perlakuan Isolat Bakteri Terhadap Pertumbuhan Benih pada Uji Roller Test

\begin{tabular}{lrlrllllll}
\hline & \multicolumn{7}{c}{ Parameter pengamatan* } \\
\cline { 2 - 8 } Perlakuan & $\begin{array}{c}\text { Persentase } \\
\text { perkecambahan } \\
\text { benih }(\%)\end{array}$ & $\begin{array}{c}\text { Panjang } \\
\text { akar }(\mathrm{cm})\end{array}$ & $\begin{array}{c}\text { Tinggi } \\
\text { tanaman } \\
(\mathrm{cm})\end{array}$ & $\begin{array}{c}\text { Tinggi } \\
\text { total }(\mathrm{cm})\end{array}$ \\
\hline BS09 & 94,56 & ab & 8,08 & $\mathrm{c}$ & 4,03 & $\mathrm{~d}$ & 12,12 & $\mathrm{c}$ \\
BP18 & 97,22 & a & 10,98 & a & 6,04 & b & 17,03 & a \\
BS41 & 100,00 & a & 11,76 & a & 6,80 & a & 18,56 & a \\
BT1 & 94,44 & ab & 9,06 & b & 5,72 & b & 14,79 & b \\
BT2 & 89,11 & b & 11,94 & a & 5,61 & b & 17,55 & a \\
BT3 & 100,00 & a & 6,03 & d & 4,91 & c & 10,94 & c \\
BT4 & 100,00 & a & 3,87 & e & 2,52 & e & 6,401 & d \\
Kontrol & 96,67 & ab & 9,19 & b & 2,52 & e & 11,72 & c \\
\hline
\end{tabular}

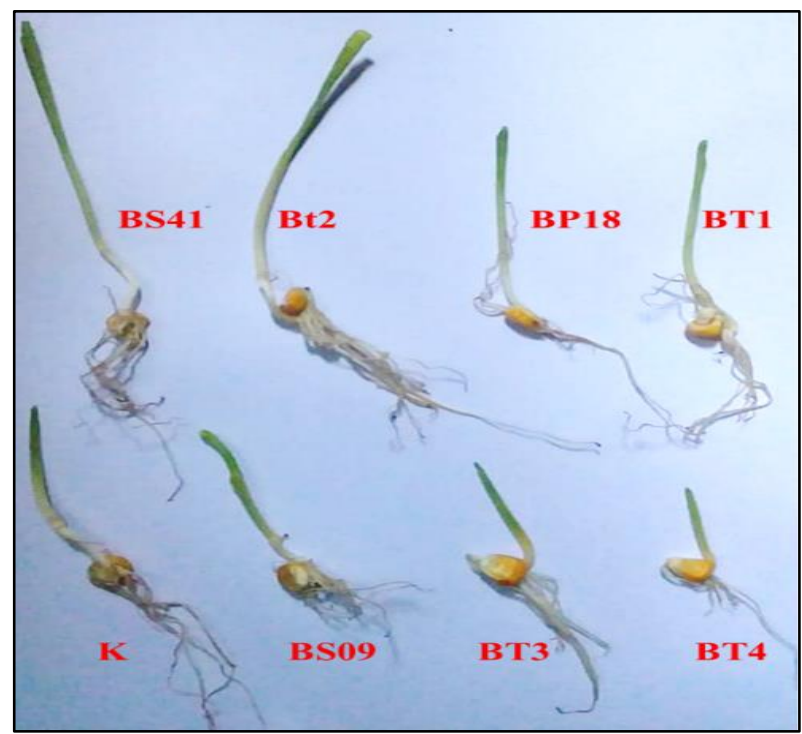

Gambar 1. Pengaruh perlakuan isolat-isolat Bacillus terhadap perkecambahan jagung

Kemampuan bakteri dalam meningkatkan pertumbuhan tanaman dipengaruhi oleh beberapa faktor. Diantaranya pengaruh isolat dalam penambatan nitrogen, pelarut fosfat, siderofor, dan fitohormon (Rahni, 2012; Zainudin, Abadi, \& Aini, 2014). Berdasarkan hasil uji terhadap benih jagung tersebut, selanjutnya empat isolat terbaik dipilih untuk pengujian terhadap penekanan penyakit 
bulai dan pertumbuhan jagung di rumah kaca, yakni: isolat $B$. polymyxa strain BP18, Bacillus subtilis strain BS41, Bacillus sp. strain BT1, dan Bacillus sp. strain $\mathrm{BT} 2$.

\section{Pengaruh Perlakuan Isolat-Isolat Bacillus Terhadap Pertumbuhan Tanaman Jagung}

Perlakuan isolat B. polymyxa strain BP18, Bacillus subtilis strain BS41, Bacillus sp. strain BT1, dan Bacillus sp. strain BT2 menujukkan pengaruh yang berbeda dan lebih baik dibandingkan kontrol. Perlakuan isolat bakteri BP18, BT1, dan BT2 memberikan pengaruh yang signifikan terhadap pertumbuhan tanaman jagung pada 28 HST (Tabel 5). Isolat-isolat Bacillus mampu meningkatkan tinggi tanaman hingga $32.7 \%$ dibanding kontrol yang ditunjukkan oleh perlakuan isolat Bacillus sp. strain BT1. Hal ini disebabkan karena Bacillus memiliki kemampuan sebagai pemacu pertumbuhan atau dikenal sebagai plant-growth promoting rhizobacteria (PGPR). Bacillus spp. telah dilaporkan mampu memproduksi prekursor fitohormon, seperti: indole acetic acid (IAA), melarutkan fosfat, dan memproduksi siderofor (Kashyap et al., 2019; Sivasakthi, Usharani, \& Saranraj, 2014). Bahkan media kompos dari limbah organik yang difermentasi dengan Bacillus sp. tetap dapat meningkatkan pertumbuhan tanaman jagung (Khoiri \& Mualim, 2018)

Tabel 5. Pengaruh Perlakuan Isolat Bakteri Terhadap Tinggi Tanaman Jagung

\begin{tabular}{lllll}
\hline Perlakuan & \multicolumn{4}{c}{ Rata-rata tinggii tanaman $(\mathrm{cm})$} \\
\cline { 2 - 5 } & $7 \mathrm{HST}$ & $14 \mathrm{HST}$ & $21 \mathrm{HST}$ & $28 \mathrm{HST}$ \\
\hline BP18 & $28,83 \mathrm{ab}$ & $42,14 \mathrm{a}$ & $63,11 \mathrm{a}$ & $80,03 \mathrm{~b}$ \\
BS41 & $27,08 \mathrm{ab}$ & $39,64 \mathrm{a}$ & $58,48 \mathrm{a}$ & $69,09 \mathrm{ab}$ \\
BT1 & $30,09 \mathrm{bc}$ & $42,62 \mathrm{a}$ & $63,92 \mathrm{a}$ & $81,68 \mathrm{~b}$ \\
BT2 & $32,57 \mathrm{c}$ & $46,38 \mathrm{a}$ & $67,88 \mathrm{a}$ & $76,67 \mathrm{~b}$ \\
Kontrol & $26.03 \mathrm{a}$ & $45,25 \mathrm{a}$ & $56,85 \mathrm{a}$ & $61,14 \mathrm{a}$
\end{tabular}

Keterangan: *angka yang diikuti huruf yang sama pada kolom yang sama tidak menunjukkan perbedaan nyata pada uji Duncan dengan taraf nyata $(\alpha) 5 \%$; HST=hari setelah tanam

\section{Pengaruh Perlakuan Isolat-Isolat Bacillus Terhadap Kejadian \& Keparahan Penyakit Bulai}

Pengujian penekanan penyakit bulai dilakukan pada kondisi terkontrol di rumah kaca. Sebelum melakukan pengujian penekanan penyakit, diperlukan isolat bulai yang akan digunakan sebagai inokulum. Inokulum diperoleh dari lapangan dengan gejala yang khas kekuningan seperti pada Gambar 2. Berdasarkan pengamatan mikroskopik bentuk konidia cendawan penyebab bulai tersebut menunjukkan bahwa konidia berbentuk bulat, berdiding tipis, dan pecabangan konidiofor 3-4 cabang teridentifikasi sebagai $P$. maydis sama seperti yang telah dilaporkan Rustiani et al. (2015).
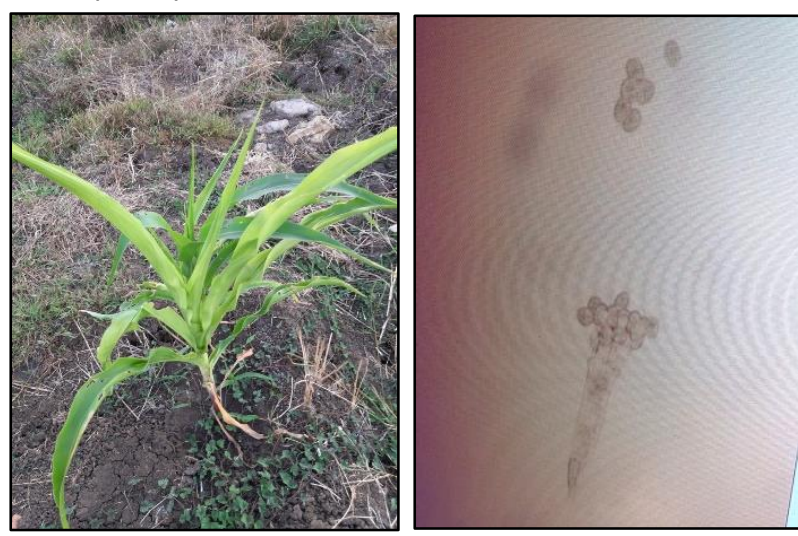

Gambar 2. Sumber inokulum bulai pada tanaman jagung di lahan (A) dan hasil pengamatan konidia secara mikroskopik pada perbesaran 400 kali (B)

Infeksi patogen dapat ditunjukkan dengan gejala yang muncul. Aplikasi mikroba agens hayati dapat mempengaruhi virulensi patogen. Berdasarkan pengamatan pada percobaan, isolat $B$. polymixa strain BP18 dapat menghambat munculnya gejala penyakit bulai tiga hari lebih lambat dari pada kontrol (Tabel 3). Meningkatnya umur tanaman dapat menyebabkan resistensi jagung terhadap bulai (Zainudin et al., 2014). Gejala-gejala penyakit yang teramati pada perlakuan bervariasi, mulai dari ringan, sedang, hingga berat (Gambar 3). Perbedaan keparahan gejala yang ditimbulkan dijadikan sebagai dasar skoring. Menurut Ahuja dan Payak (1983), skoring bulai diklasifikasikan berdasarkan persentase gejala dengan skala 1 hingga skala 5 .

Tabel 6. Pengaruh Perlakuan Isolat Bakteri Terhadap Periode Inkubasi

\begin{tabular}{lc}
\hline Perlakuan & $\begin{array}{c}\text { Rerata periode inkubasi } \\
(\text { HST })\end{array}$ \\
\hline BP18 & 14,11 \\
BS41 & 13,73 \\
BT1 & 12,63 \\
BT2 & 11,46 \\
Kontrol & 11,28 \\
\hline
\end{tabular}

Perlakuan isolat bakteri dapat memberikan pengaruh terhadap kejadian dan keparahan penyakit, laju infeksi, nilai area di bawah kurva perkembangan penyakit (AUDPC), dan indeks proteksi. Berdasarkan pengamatan selama 35 HST secara umum seluruh isolat memberikan pengaruh 
terhadap kejadian penyakit. Isolat-isolat Bacillus spp. mampu menekan kejadian penyakit bulai berkisar antara 60.16 hingga 80,85\%. Penekanan terbaik terhadap kejadian penyakit bulai ditunjukkan oleh Isolat B. polymixa strain BP18 (Gambar 4).
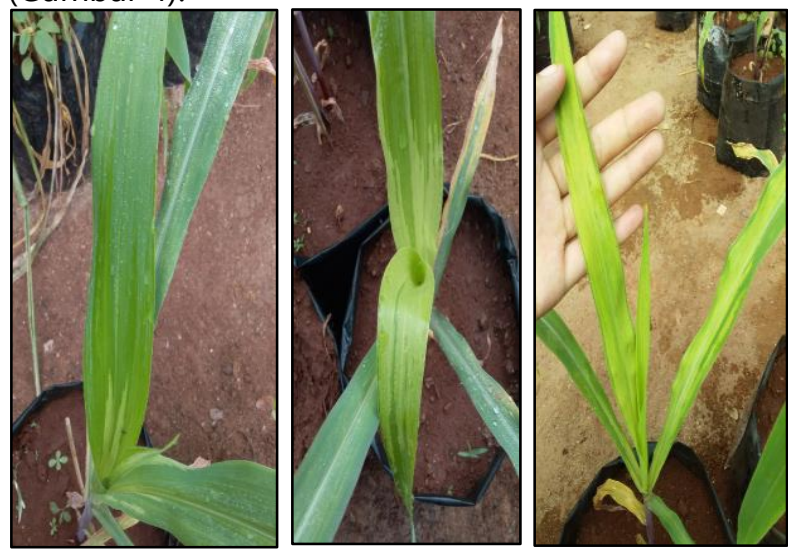

Gambar 3 Gejala-gejala yang teramati pada tanaman jagung di rumah kaca ( $A=$ gejala ringan, $B=$ gejala sedang,$C=$ gejala berat)

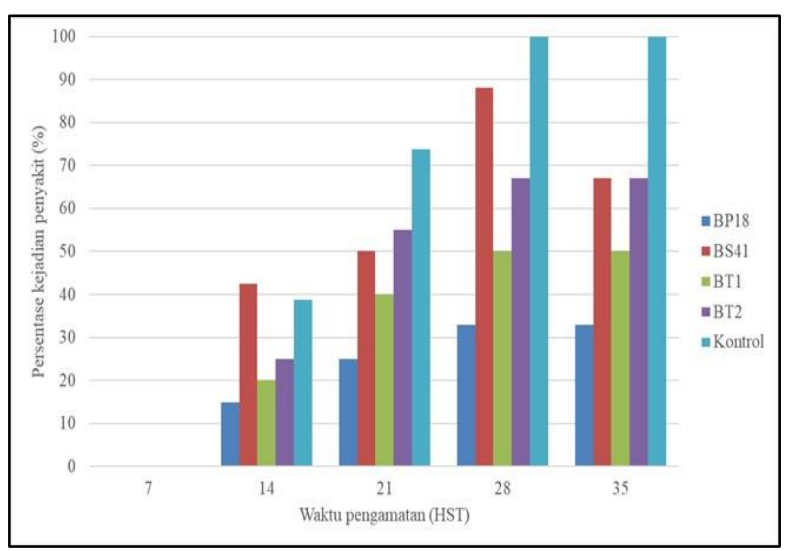

Gambar 4. Grafik pengaruh perlakuan isolat terhadap kejadian penyakit bulai pada tanaman jagung

Berdasarkan data keparahan penyakit, Isolatisolat Bacillus spp. yang diuji mampu menekan perkembangan keparahan penyakit. Penekanan perkembangan penyakit bulai terbaik ditunjukkan oleh isolat Bacillus sp. strain BT1 (Gambar 5). Perlakuan isolat-isolat Bacillus spp. juga mampu menekan laju perkembangan penyakit $(r)$ dan nilai luas area kurva perkembangan penyakit. Laju perkembanagn penyakit adalah tingkat perubahan kejadian dan keparahan penyakit dari waktu ke waktu, Laju perkembangan penyakit terkecil ditunjukkan isolat Bacillus sp. strain BT2 dengan nilai 0,052 (Tabel 7). Hal ini menunjukkan perkembangan penyakit pada perlakuan Bacillus sp. strain BT2 adalah paling lambat dibandingkan dengan perlakuan lainnya. Perlakuan menggunakan isolat lain juga menunjukkan laju perkembangan penyakit yang lebih rendah dibandingkan dengan kontrol. Secara total, penilaian keparahan penyakit berdasarkan nilai AUDPC menunjukkan isolat Bacillus sp. strain BT1 memiliki nilai paling rendah yakni 3,94 dan memiliki nilai indeks proteksi tertinggi yakni mencapai 82,71\% (Tabel 7).

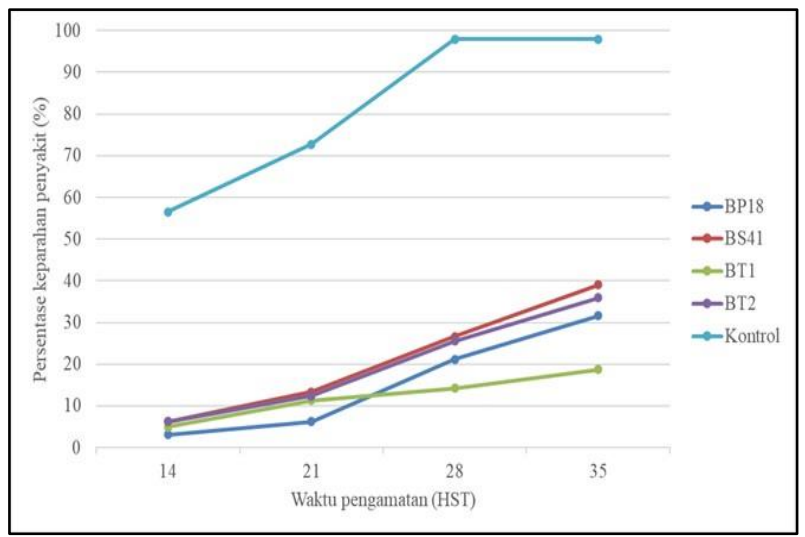

Gambar 5. Grafik perkembangan keparahan penyakit bulai pada tanaman jagung

Tabel 7. Pengaruh perlakuan Bacillus spp. terhadap nilai laju perkembangan penyakit ( $r$ ), luas area dibawah kurva perkembangan penyakit (AUDPC), dan indeks proteksi.

\begin{tabular}{lccc}
\hline Perlakuan & $\begin{array}{c}\text { Laju } \\
\text { perkembangan } \\
\text { penyakit }(r)\end{array}$ & AUDPC & $\begin{array}{c}\text { Indeks } \\
\text { proteksi } \\
(\%)\end{array}$ \\
\hline BP18 & 0,062 & 5,09 & 77,50 \\
BS41 & 0,053 & 6,90 & 69,50 \\
BT1 & 0,053 & 3,94 & 82,71 \\
BT2 & 0,052 & 6,51 & 71,22 \\
Kontrol & 0,069 & 22,62 & - \\
\hline
\end{tabular}

Kemampuan Bacillus spp. sebagai PGPR dalam memacu pertumbuhan dan mengendalikan penyakit tumbuhan dapat terjadi dengan dua mekanisme, yaitu: langsung dan tidak langsung. Mekanisme secara langsung dengan menghasilkan fitohormon, pelarut fosfat, ammonia, dan siderofor. Sedangkan mekanisme tidak langsung melalui kompetisi nutrisi dan ruang dengan cara antibiosis, enzim pelisis patogen, dan senyawa volatil (Kashyap et al., 2019). Beberapa agens hayati lain juga telah dilaporkan mampu mengurangi keparahan penyakit bulai, seperti: Pseudomonas sp., Trichoderma spp. (Jatnika, Abadi, \& Aini, 2014; Sutama, Ratih, Maryono, \& Ginting, 2015). 


\section{KESIMPULAN}

Berdasarkan hasil yang diperoleh dapat disimpulkan bahwa isolat BS09, BP18, BS41, BT1, BT2, BT3, dan BT4 bersifat nonpatogenik terhadap jagung. Isolat BP18, BS41, BT1, dan BT2 dapat memacu pertumbuhan bibit jagung. Dalam uji penekanan penyakit bulai yang disebabkan oleh $P$. maydis dirumah kaca menunjukkan isolat $B$. polymyxa strain BP18, Bacillus subtilis strain BS41, Bacillus sp. strain BT1, dan Bacillus sp. strain BT2 dapat menekan kejadian, keparahan, dan laju perkembangan penyakit. Isolat terbaik yang mampu menekan penyakitbulai berdasarkan percobaan tersebut adalah isolat Bacillus sp. strain BT1 dengan nilai AUDPC terkecil $(3,94)$ dan indeks proteksi tertinggi $(82,71 \%)$.

\section{Saran}

Perlu dilakukan penelitian lebih lanjut terhadap mekanisme penghambatan dan pemacu pertumbuhan yang dimiliki oleh isolat-isolat koleksi, serta pengujian pada lingkungan sebenarnya.

\section{UCAPAN TERIMA KASIH}

Penulis menyampaikan ucapan terima kasih kepada Lembaga Penelitian dan Pengabdian kepada Masyarakat, Universitas Trunojoyo Madura yang telah membiayai sebagian penelitian ini melalui Hibah Penelitian Mandiri Universitas Trunojoyo Madura pada Skema Penelitian Pemula Tahun 2020

\section{DAFTAR PUSTAKA}

Adhi, S. R., Widiantini, F., \& Yulia, D. E. (2019). Metode inokulasi buatan untuk menguji infeksi Peronosclerospora maydis penyebab penyakit bulai tanaman jagung. Jurnal Agro, 6(1), 77-86.

Ahuja, S. C., \& Payak, M. M. (1983). A rating scale for banded leaf and sheath blight of maize. Indian Phytopathology (India).

Amran, M., Suriany, K. S., \& Nurnina, N. (2018). Penyakit Bulai pada Tanaman Jagung. Balitsereal.

Anahosur, K. H. (1980). Chemical Control of Sorghum Downy Mildew in India. Plant Disease, 64(11), 1004. https://doi.org/10.1094/pd-641004

Badan Pusat Statistik (BPS). (2018). Produktivitas
Jagung Nasional. Retrieved from http://bps.go.id

Bonman, J. M., Paisooksantivatana, Y., \& Pitipornchai, P. (1983). Host range of Peronosclerospora sorghi in Thailand. Plant Disease, 67(6), 630-632.

Caulier, S., Gillis, A., Colau, G., Licciardi, F., Liépin, M., Desoignies, N., ... Bragard, C. (2018). Versatile Antagonistic Activities of Soil-Borne Bacillus spp. and Pseudomonas spp. against Phytophthora infestans and Other Potato Pathogens. Frontiers in Microbiology, Vol. 9, p. 143. Retrieved from https://www.frontiersin.org/article/10.3389/fmic b. 2018.00143

Daryono, B. S., Parazulfa, A., \& Purnomo, P. (2018). Uji ketahanan tujuh kultivar jagung (Zea mays L.) terhadap penyakit bulai (Peronosclerospora spp.). Biogenesis: Jurnal Ilmiah Biologi, 6(1), 1117.

Isakeit, T., \& Jaster, J. (2005). Texas has a new pathotype of Peronosclerospora sorghi, the cause of sorghum downy mildew. Plant Disease, 89(5), 529.

ISTA. (2017). International Rules for Seed Testing. https://doi.org/10.15258/istarules.2017.02

Jatnika, W., Abadi, A. L., \& Aini, L. Q. (2014). Pengaruh aplikasi Bacillus sp. dan Pseudomonas $\mathrm{sp}$. terhadap perkembangan penyakit bulai yang disebabkan oleh jamur patogen Peronosclerospora maydis pada tanaman jagung. Jurnal Hama Dan Penyakit Tumbuhan, 1(4), pp-19.

Kashyap, B. K., Solanki, M. K., Pandey, A. K., Prabha, S., Kumar, P., \& Kumari, B. (2019). Bacillus as plant growth promoting rhizobacteria (PGPR): a promising green agriculture technology. In Plant health under biotic stress (pp. 219-236). Springer.

Kementerian Pertanian. (2019). Data lima tahun terakhir sub-sektor tanaman pangan. Retrieved from

https://www.pertanian.go.id/Data5tahun/TPATA P-2017(pdf)/23-ProdJagung.pdf

Khoiri, S., \& Mualim, M. (2018). Fermentasi Limbah Jagung dan Pengaruhnya terhadap Pertumbuhan Jagung Ungu Introduksi di Madura. Agrovigor: Jurnal Agroekoteknologi, 11(2), 96-100. 
Kusumanigtyas, R. (2015). Efektivitas formulasi bakteri berbahan aktif Pseudomonas diminuta, Pseudomonas mallei, dan Bacillus mycoides pada berbagai bahan pembawa seabagai bionematisida untuk mengendalikan nematoga sista kentang (Globodera rostochiensis). Universitas Jember.

Matruti, A. E., Kalay, A. M., \& Uruilal, C. (2018). Serangan Perenosclerospora spp Pada Tanaman Jagung Di Desa Rumahtiga, Kecamatan Teluk Ambon Baguala Kota Ambon. Agrologia, 2(2).

Pakki, S. (2017). Kelestarian ketahanan varietas unggul jagung terhadap penyakit bulai Peronosclerospora maydis. Jurnal Penelitian Pertanian Tanaman Pangan, 1(1), 37-44.

Rahni, N. M. (2012). Efek Fitohormon PGPR terhadap pertumbuhan tanaman jagung (Zea mays). CEFARS: Jurnal Agribisnis Dan Pengembangan Wilayah, 3(2), 27-35.

Rashid, Z., Zaidi, P. H., Vinayan, M. T., Sharma, S. S., $\&$ Setty, T. A. S. (2013). Downy mildew resistance in maize (Zea mays L.) across Peronosclerospora species in lowland tropical Asia. Crop Protection, 43, 183-191.

Rustiani, U. S., Sinaga, M. S., Hidayat, S. H., \& Wiyono, S. (2015). Tiga spesies Peronosclerospora penyebab penyakit bulai jagung di Indonesia. Berita Biologi, 14(1), 29-37.

Sireesha, Y., \& Velazhahan, R. (2016). Biological control of downy mildew of maize caused by Peronosclerospora sorghi under environmentally controlled conditions. Journal of Applied and Natural Science, 8(1), 279-283. https://doi.org/10.31018/jans.v8i1.786

Sivasakthi, S., Usharani, G., \& Saranraj, P. (2014). Biocontrol potentiality of plant growth promoting bacteria (PGPR)-Pseudomonas fluorescens and Bacillus subtilis: a review. African Journal of Agricultural Research, 9(16), 12651277.

Sutama, K., Ratih, S., Maryono, T., \& Ginting, C. (2015). Pengaruh bakteri Paenibacillus polymyxa dan jamur Trichoderma sp. terhadap penyakit bulai (Peronosclerospora maydis (Rac.) Shaw) pada tanaman jagung. Jurnal Agrotek Tropika, 3(2), 199-203.

Ulhaq, M. A., \& Masnilah, R. (2019). Pengaruh Penggunaan Beberapa Varietas dan Aplikasi Pseudomonas fluorescens untuk Mengendalikan Penyakit Bulai (Peronosclerospora maydis) pada Tanaman Jagung (Zea mays L.). Jurnal Pengendalian Hayati, 2(1), 1-9.

Vidhyasekaran, P., \& Muthamilan, M. (1995). Development of formulations of Pseudomonas fluorescens for control of chickpea wilt. Plant Disease (USA).

Zainudin, Z., Abadi, A. L., \& Aini, L. Q. (2014). Pengaruh pemberian Plant Growth Promoting Rhizobacteria (Bacillus subtilis dan Pseudomonas fluorescens) terhadap penyakit bulai pada tanaman jagung (Zea mays L.). Jurnal Hama Dan Penyakit Tumbuhan, 2(1), pp-11. 